DOI: $10.47743 /$ jss-2021-67-4-25

\title{
Aspecte de drept comparat privind metodele speciale de supraveghere sau cercetare utilizate în lupta împotriva criminalităţii informatice în legislaţia din România şi Republica Moldova
}

\section{Aspects of Comparative Law Regarding the Special Methods of Surveillance or Research Used in the Fight Against Computer Crime in the Legislation of Romania and the Republic of Moldova}

\section{Vasile Popa ${ }^{1}$}

\begin{abstract}
Rezumat: În ultimii ani, favorizată şi de situaţia pandemică, s-a observat că în timp ce lumea digitală aduce beneficii enorme, creează şi mari vulnerabilităţi. Incidentele din spaţiul virtual sunt în creştere la un nivel alarmant şi ar putea perturba furnizarea de servicii esenţiale, prin ameninţări cu origini diferite, îndreptate atât asupra persoanelor fizice cât şi juridice. Internetul, ca instrument principal al criminalităţii informatice, prezinta o infinitate de utilizări, ceea ce duce în mod inevitabil la diversificarea formelor de manifestare a fenomenului. Menţinerea unei siguranţe în mediul informatic a devenit o prioritate a securităţii tuturor statelor, care potrivit convenţiilor şi tratatelor internaţionale se poate realiza prin, cunoaşterea, prevenirea şi contracararea atacurilor şi ameninţărilor, precum şi prin diminuarea vulnerabilităţilor infrastructurilor cibernetice în scopul gestionării eficiente a tuturor riscurilor la adresa securităţii acestora, prevenirea şi combaterea criminalităţii informatice şi nu în ultimul rând apărarea cibernetică. Contribuţia în săvârşirea faptelor penale a mijloacelor informatice, au motivat reglementarea unor procedee probatorii speciale, adaptate la lumea în care trăim, a căror utilizare facilitează procesul de tragere la răspundere penală a persoanelor care comit infracţiuni.
\end{abstract}

Cuvinte-cheie: procedee probatorii; criminalitate informatică; măsuri speciale de supraveghere; proces penal

\begin{abstract}
In recent years, also favored by the pandemic situation, it has been observed that while the digital world brings enormous benefits, it also creates great vulnerabilities. Incidents in the virtual space are growing at an alarming level and could disrupt the provision of essential services, through threats with different origins, aimed at both individuals and legal entities. The Internet, as the main tool of cybercrime, has an infinite number of uses, which inevitably leads to the diversification of the manifestations of the phenomenon. Maintaining security in the IT environment has become a priority for the
\end{abstract}

\footnotetext{
${ }^{1}$ Doctorand, Universitatea de Stat din Moldova, Școala Doctorală Știinte Juridice, e-mail: sile_popa18@yahoo.com.
} 
security of all states, which according to international conventions and treaties can be achieved by knowing, preventing and countering attacks and threats, as well as by reducing the vulnerabilities of cyber infrastructures in order to effectively manage all risks. addressing their security, preventing and combating cybercrime and last but not least cyber defense. The contribution in committing the criminal acts to the computer means, motivated the regulation of special evidentiary procedures, adapted to the world in which we live, whose use facilitates the process of prosecuting the persons who commit crimes.

Keywords: evidentiary procedures; cybercrime; special surveillance measures; criminal proceedings

Dezvoltarea fulminantă a tehnologiei a creat, pe lângă numeroase beneficii, şi situaţii mai puţin plăcute; putem spune că a deschis adevărate oportunităţi pentru încălcări greu de detectat şi combătut şi care produc permanent prejudicii însemnate.

August Beguai menţiona într-un studiu că, în timp ce în 1984 al lui Orwell oamenii se aflau sub ochiul Marelui Frate şi al Poliţiei Secrete a acestuia, astăzi se află sub ochiul marilor sisteme informatizate. Fără lege şi ordine în această societate informatizată declinul va fi în mod cert provocat chiar de aceste cuceriri tehnologice care pe de altă parte aduc atâtea beneficii omenirii.

Despre sistemul judiciar din Republica Moldova, de după anul 1991 s-a afirmat că reformarea a fost realizată pe cale evoluţionară şi nu revoluţionară, sistemul anterior constituind baza noii puteri judiciare, cu toate că legile noi au instituit noi raporturi şi organisme statale în sistemul judiciar. Vechiul sistem legislativ, oricâte completări, modificări sau abrogări de texte ar suporta, rămâne expresia unei anumite perioade istorice, astfel subliniază că noul sistem de justiţie nu poate apărea din nimic ori în baza inspiraţiei iniţiatorilor sau cu fragmente de idei selectate aleatoriu din experienţa altor state, ci doar având la bază o seamă de obiceiuri, tradiţii şi precedente, scopul fiind afirmarea şi consolidarea statului de drept şi al edificiului democratic privind înfăptuirea justiţiei ${ }^{2}$.

Necesitatea reglementării prin norme juridice a domeniului delicat al activităţii speciale de investigaţii s-a materializat iniţial prin Legea nr. 45/1994³ , ca regim extrajudiciar de activităţi şi investigaţii operative, asociate vechilor coduri penale şi de procedură penală şi care în mod generic, a fost definită ca fiind „primul act normativ ce reglementează deschis activitatea secretă a serviciilor speciale şi în care au fost concentrate şi unificate reguli de bază privind activitatea cotidiană,

${ }^{2}$ T. Osoianu, Reforma judiciară și de drept în Republica Moldova. Condiție necesară în vederea integrării europene, [Online] la http: //www.ipp.md/old/print.php?l=ro\&idc=167\& $\mathrm{id}=495$, p. 1-2, 15 și Apud din Мартынчик Е., Судебная власть в Молдове, часть первая (историко-правовые очерки), Изд-во ULIM, Chiєinгu, 1999, p. 23, accesat 31.03.2019.

${ }^{3}$ Legea nr. 45/12.04.1994 privind activitatea operativă de investigații (A.S.I.), publicată în Monitorul Oficial al Republicii Moldova nr. 11-13/1994, abrogată prin Legea nr. 59/29.03.2012, accesat 31.03.2019. 
fără excepţii, a organelor investite cu dreptul de a efectua activitatea operativă de investigaţii"4.

Conform Legii nr. 45/1994, activitatea operativă de investigaţii, constituie un mijloc juridic de stat, de apărare a intereselor statului, integrităţii teritoriale, drepturilor şi intereselor legitime ale persoanelor, a tuturor formelor de proprietate contra atentatelor criminale, cu sarcini de: relevarea atentatelor criminale, prevenirea, curmarea, descoperirea infracţiunilor şi a persoanelor care le organizează, le comit sau le-au comis, precum şi compensării daunei cauzate de infracţiune; căutarea persoanelor care se ascund de organele de urmărire penală sau de judecată sau care se sustrag de la sancţiunea penală şi a celor dispăruţi fără urmă; colectarea de informaţii despre evenimentele sau acţiunile care pun în pericol securitatea de stat, militară, economică sau ecologică a ţării, desfăşurată în baza principiilor legalităţii, respectării drepturilor omului şi libertăţilor persoanei, oportunităţii şi ofensivităţii, îmbinării metodelor publice şi secrete, cooperării cu alte organe de stat, dez-ideologizării şi nepărtinirii.

Normele nepublice, conspirate sunt condiţionate a se aplica numai în cazul în care este imposibilă o altă cale, în scopul îndeplinirii sarcinilor activităţii operative de investigaţii necesare pentru asigurarea securităţii naţionale, ordinii publice, bunăstării economice, menţinerii ordinii de drept şi prevenirea sau descoperirea infracţiunilor grave, deosebit de grave şi excepţional de grave, pentru ocrotirea sănătăţii, protejarea moralităţii ori pentru apărarea drepturilor şi libertăţilor altor persoane.

Activităţile concrete conform articolului 6 din Legea nr. 45/1994 sunt distribuite a se realiza, astfel: cu autorizarea judecătorului de instrucţie (cercetarea domiciliului şi instalarea în el a aparatelor audio, video, de fotografiat, de filmat; supravegherea domiciliului prin utilizarea mijloacelor tehnice; interceptarea convorbirilor telefonice şi a altor convorbiri; controlul comunicărilor telegrafice şi a altor comunicări; culegerea informaţiei de la instituţiile de telecomunicaţii); alte măsuri operative de investigaţii (chestionarea; culegerea informaţiei; urmărirea vizuală; urmărirea şi documentarea cu ajutorul metodelor şi mijloacelor tehnice moderne; colectarea mostrelor pentru cercetarea comparativă; efectuarea achiziţiilor de control şi a controlului livrărilor de mărfuri şi producţie aflate în circulaţie liberă sau limitată; cercetarea obiectelor şi actelor; identificarea persoanei; cercetarea încăperilor, clădirilor, porţiunilor de teren şi a mijloacelor de transport; cercetarea corespondenţei condamnaţilor; ţinerea convorbirilor; aplicarea detectorului comportamentului simulat; marcarea cu substanţe chimice şi alte substanţe speciale; experimentul operativ; infiltrarea operativă în organizaţiile criminale a colaboratorilor titulari din subdiviziunile operative şi a persoanelor care colaborează în mod confidenţial cu organele care exercită activitate operativă de investigaţii, utilizând acte de identitate şi alte documente de acoperire; controlul

${ }^{4}$ I. Covalciuc, „Reflexii asupra evoluției istorice a reglementărilor normative privind activitățile speciale de investigații”, în Revista Națională de Drept, nr. 11/2016, p. 57. 
transmiterii banilor sau altor valori materiale extorcate; monitorizarea tranzacţiilor efectuate prin unul sau mai multe conturi bancare).

Problematica definirii regimului extrajudiciar al activităţii speciale de investigaţii a fost abordată ${ }^{5}$, ca necesitate teoretico-practică de clarificare a următoarelor proceduri de bază: documentarea ca varietate de cunoaştere a fenomenelor lumii înconjurătoare; stabilirea adevărului obiectiv în calitate de scop al documentării; sarcinile şi obiectul documentării; sursele şi mijloacele documentării; conţinutul procesului de documentare; reglementarea juridică a documentării; particularităţile documentării în timpul realizării măsurilor operative de investigaţii. Despre documentare, ca mijloc de realizare a activităţilor speciale de investigaţii se apreciază că are rolul studierii şi descoperii modalităţilor de cunoaştere a adevărului realizabil, atât generic (declaraţii persoane vătămate, martori, concluzii specialişti, documente obţinute, urme fixate, înscrieri foto, audio, video sau alţi purtători de informaţii). De asemenea, are şi rolul specific prin norme certe şi regulamente departamentale, susţinute de teorie atât cunoaşterea materializată prin colectarea, verificarea, aprecierea şi fixarea, cât şi activitatea, prin folosirea rezultatelor obţinute în procedura judiciară, toate având caracter sistemic şi de concentrare a datelor operative despre persoană, fapte, trecut infracţional, legături, ca obiectiv esenţial în realizarea sarcinilor concrete activităţii speciale de investigaţii. Rezultă că dualitatea măsurilor speciale de investigare extrajudiciare şi convergenţa cu normele procesual penale sau de securitate naţională, este apreciată şi din perspectiva obiectelor țintă şi anume: obiecte ce au legătură cu faptul infracţiunii, circumstanţele ce necesită a fi stabilite în cadrul unui dosar penal obiect al probaţiunii, precum şi - colectarea de informaţii despre evenimente sau acţiuni care pun în pericol securitatea de stat normă reglementată diferit.

Este relevantă comparaţia: documentare prin activitate operativă de investigaţii - probatoriu prin măsuri procesual penale, susţinută din perspectiva asistării, prin cunoaşterea evenimentelor care au avut loc în trecut, a celor care se află în proces de pregătire sau în prezent se desfăşoară, precum şi a celor care datorită situaţiei create pot să survină în viitor. Este necesar a fi colectate şi informaţii de la participanţii la procedură (persoane care acordă asistenţă organelor operative de investigaţii sau colaboratorii operativi) privind actele pregătitoare sau în desfăşurare având posibilitatea urmăririi mijlocit sau nemijlocit a parcursului. Mărturia acestora ar duce la clarificarea fără dubiu a infracţiunii, fiind îndeplinit obiectivul probatoriului procesul penal determinat de circumstanţele ce urmează a fi dovedite în procesul penal şi anume: faptele referitoare la existenţa elementelor infracţiunii, precum şi cauzele care înlătură caracterul penal al faptei; circumstanţele prevăzute de lege care atenuează sau agravează răspunderea penală a făptuitorului; datele personale care caracterizează inculpatul şi victima; caracterul şi mărimea daunei cauzate prin infracţiune; existenţa bunurilor destinate sau

${ }^{5}$ I. Carlașuc, „Regimul extrajudiciar al activității operative de investigații în realizarea sarcinilor stabilite prin lege”, în Revista Teorii și practici de guvernări democraticel Materialele sesiunii de comunicări științifice 23-24.10.2010, Chișinău, [Online] la http: //iso.fd.md/caiet_site/caiet_nr. 4.pdf/pg.418-423, accesat 31.03.2019. 
utilizate pentru săvârşirea infracţiunii sau dobândite prin infracţiune, indiferent cui au fost transmise; toate circumstanţele relevante la stabilirea pedepsei.

Garanţia respectării drepturilor şi libertăţilor fundamentale este susţinută prin concentrarea materialelor în dosarele de evidenţă operativă, utilizate în situaţiile de solicitare în vederea punerii în aplicare, extrajudiciar, a măsurilor operative care limitează drepturile constituţionale ale persoanelor, întemeiate pe date veridice, supuse autorizării judecătorului de instrucţie. Controlul judiciar al măsurilor speciale de investigaţii, prin faptul că verificările operative care vizează drepturile constituţionale ale persoanelor precum şi libertăţile fundamentale, se efectuează numai după autorizarea prealabilă a acestuia.

Fundamentarea statutului unic al judecătorului de instrucţie, conform normelor de procedură penală, în opinia autorului, îi conferă acestuia atribuţii proprii de urmărire penală, dar şi de control judiciar asupra acţiunilor procesuale efectuate în cadrul urmăririi penale.

Adoptarea Noilor Coduri Penale şi de Procedură Penală $\breve{a}^{6}$ au determinat reaşezarea activităţii speciale de investigaţii pe o altă lege, astfel, prin Legea nr. 59 din 29.03.2012 $2^{7}$, noţiunea este definită ca „o procedură cu caracter secret şi/sau public, efectuată de autoritățile competente, cu sau fără utilizarea echipamentelor tehnice speciale, în scopul culegerii de informaţii, necesare pentru prevenirea şi combaterea criminalităţii, asigurarea securităţii statului, ordinii publice, apărarea drepturilor şi intereselor legitime ale persoanelor, descoperirea şi cercetarea infracţiunilor". Activităţile sunt organizate în trei categorii distincte: cu autorizarea judecătorului de instrucţie: cercetarea domiciliului şi/sau instalarea în el a aparatelor ce asigură supravegherea şi înregistrarea audio şi video, a celor de fotografiat şi filmat; supravegherea domiciliului prin utilizarea mijloacelor tehnice ce asigură înregistrarea; interceptarea şi înregistrarea comunicărilor şi imaginilor; reţinerea, cercetarea, predarea, percheziţionarea sau ridicarea trimiterilor poştale; monitorizarea conexiunilor comunicaţiilor telegrafice şi electronice; monitorizarea sau controlul tranzacţiilor financiare şi accesul la informaţia financiară; documentarea cu ajutorul metodelor şi mijloacelor tehnice, precum şi localizarea sau urmărirea prin sistem de poziţionare globală ori prin alte mijloace tehnice; colectarea informaţiei de la furnizorii de servicii de comunicaţii electronice, toate aceste măsuri fiind autorizate a se efectua, la solicitarea procurorului, doar în cadrul unui dosar penal; cu autorizarea procurorului: identificarea abonatului, proprietarului sau a utilizatorului unui sistem de comunicaţii electronice ori al unui punct de acces la un sistem informatic; urmărirea vizuală; controlul transmiterii banilor sau altor valori materiale extorcate (doar în cadrul unui dosar penal); investigaţia sub acoperire; supravegherea transfrontalieră (doar în cadrul unui dosar penal); livrarea controlată (doar în cadrul unui dosar penal); colectarea mostrelor pentru cercetare comparată; cercetarea obiectelor şi a documentelor; achiziţia de control, cu excepţia

${ }^{6}$ Codul de procedură penală al Republicii Moldova (Cod nr. 122 din 14.03.2003), publicat în Monitorul Oficial al Republicii Moldova nr. 104-110 din 07.06.2003.

${ }^{7}$ Legea nr. 59 din 29.03.2012 privind activitatea specială de investigații, publicată în Monitorul Oficial al Republicii Moldova, nr. 113-118 din 08.06.2012. 
a trei din acestea, toate celelalte fiind în formă duală judiciară şi extrajudiciară; cu autorizarea conducătorului subdiviziunii specializate: chestionarea; culegerea de date despre persoane şi fapte; identificarea persoanei, toate fiind efectuate ca şi activitate extrajudiciară.

Materia normativă extra-procesuală ce vizează activitatea specială de investigaţii a fost analizată în literatura de specialitate ${ }^{8}$, în privinţa principiilor şi conţinutului acesteia. Principiile sunt „ideile, tezele fundamentale care stau la baza întregului sistem de drept" şi care se manifestă în (i) principii ce reflectă esenţa activităţii speciale de investigaţii şi trăsăturile specifice acesteia; (ii) principii care prin sine reprezintă un sistem de norme juridice, unice pentru întreaga activitate specială de investigații; dar şi pentru a determina ilegalitatea măsurilor speciale de investigaţii prin încălcarea principiilor acestei activităţi. Din punct de vedere teoretic, au fost trasate criterii în funcţie de gradul de concretizare şi gradul de răspândire. De apreciat ca esenţiale în ceea ce priveşte finalitatea activităţii speciale de investigaţii sunt: principiile constituţionale ale activităţii speciale de investigaţii şi alte principii ale activităţii ce rezultă din legea cu privire la activitatea specială de investigaţii sau alte acte normative. Sub aspect gnoseologic, îndeplinirea duală a atribuţiilor ca finalitate în activitatea specială de investigaţii, se face astfel: a) în cadrul procesului penal: protejarea persoanei, societăţii şi statului de infracţiuni, precum şi protejarea persoanei şi societăţii de faptele ilegale ale persoanelor cu funcţii de răspundere în activitatea lor legată de cercetarea infracţiunilor presupuse sau săvârşite, astfel că orice persoană care a săvârşit o infracţiune să fie trasă la răspundere penală potrivit vinovăţiei sale şi nicio persoană nevinovată să nu fie trasă la răspundere penală sau condamnată; b) în cadrul activităţii speciale de investigaţii: culegerea de informaţii necesare pentru prevenirea şi combaterea criminalităţii, asigurarea securităţii statului, ordinii publice, apărarea drepturilor şi intereselor legitime ale persoanelor, descoperirea şi cercetarea infracţiunilor ${ }^{9}$.

În analiza teoretico-practică a criteriilor de clasificare a măsurilor speciale de investigaţii au fost realizate o serie de analize, în care se apreciază ca importantă o astfel de activitate în scopul determinării temeiurilor şi condiţiilor de înfăptuire, activitate care în genere se bazează pe experienţa şi viziunea fiecărui specialist în domeniu. Astfel apreciem relevantă clasificarea raportată convenţional după cum urmează: a) după modul de realizare public - secret; b) după subiectul autorizării judecător de instrucţie-procuror-conducător al subdiviziunii specializate; c) după gradul de lezare al drepturilor şi libertăţilor omului: nu aduc atingere acestora care încalcă aceste drepturi; d) după intensitatea utilizării mijloacelor tehnice speciale: măsuri speciale tehnice - preponderent cu utilizarea mijloacelor tehnice fără aplicarea echipamentelor tehnice; e) după regimul lor juridic în măsuri: care se înfăptuiesc cu autorizarea judecătorului de instrucţie doar în cadrul unui proces

${ }^{8}$ V. Rusu, I. Covalciuc, „Unele reflecții asupra sistemului și conținutului principiilor activității speciale de investigații”, în Revista Națională de Drept, nr. 8/2015, pp. 51-54.

${ }^{9}$ I. Covalciuc, „Actualitatea și importanța activității speciale de investigații în contextul ultimelor modificări legislative” în Buletinul Științific al Univ. de Stat Bogdan Petriceicu Hașdeu, Științe sociale nr. 2(4)/2016, p. 179. 
penal - care se înfăptuiesc cu autorizarea procurorului doar în cadrul unui proces penal - care se înfăptuiesc cu autorizarea procurorului în cadrul unui proces penal cât şi în afara acestuia şi care se înfăptuiesc cu autorizarea conducătorului subdiviziunii specializate în afara procesului penal. În concluzie, autorul susţine că esenţa reglementării măsurilor speciale de investigaţii o constituie limitarea drepturilor omului, care determină şi categoria subiectului împuternicit cu dreptul de a o autoriza ${ }^{10}$.

Sub aspect general, se afirmă despre activitatea specială de investigaţii, ca şi alte activităţi desfăşurate de organele statului, că este îndreptată spre ocrotirea ordinii de drept, fiind strict reglementată de lege şi că se realizează printr-un sistem de măsuri publice cât şi confidenţiale, având propriile trăsături specifice. Aceste trăsături sunt :

a) caracter de sine stătător - se manifestă prin faptul că în esenţă activitatea de investigaţii presupune utilizarea unor forţe, mijloace şi metode speciale, care după formă, conţinut şi origine diferă de cele specifice activităţii de urmărire penală, administrative; caracterul autonom este determinat şi de mecanismul reglementării normative al acestei activităţi;

b) stricta legiferare - prin lege organică sunt stabilite scopurile, sarcinile, principiile, măsurile speciale de investigaţii, temeiurile şi condiţiile înfăptuirii lor, sunt prevăzute organele abilitate cu drepturi şi obligaţii. Reglementarea strictă şi detaliată permite utilizarea complexă a forţelor şi mijloacelor din dotarea organelor speciale de investigaţie, aplicarea unor metode speciale de prevenire şi combatere a infracţiunilor, căutarea persoanelor care se ascund de organele de urmărire penală sau de instanţa de judecată ori care se eschivează de la executarea pedepsei penale, a persoanelor dispărute fără urmă, precum şi soluţionarea altor sarcini prevăzute de lege aspect ce serveşte ca garant pentru respectarea legalităţii în procesul exercitării activităţii speciale de investigaţii şi prevenirea încălcărilor drepturilor şi libertăţilor constituţionale ale cetăţenilor; c) realizarea de către organe special împuternicite - activitatea specială de investigaţii este exercitată de către subdiviziunile specializate ale Ministerului Afacerilor Interne, Ministerului Apărării, Centrului Naţional Anticorupţie, Serviciului de Informaţii şi Securitate, Serviciului de Protecţie şi Pază de Stat, Serviciului Vamal şi Departamentul Instituţiilor Penitenciare al Ministerului Justiţiei;

d) exercitarea numai în vederea atingerii scopurilor şi realizării sarcinilor prevăzute în lege - înfăptuirea măsurilor speciale de investigaţii pentru realizarea scopurilor şi sarcinilor neprevăzute de legea cu privire la activitatea specială de investigaţii, nu se admite.

Din perspectiva izvoarelor şi reglementărilor diferite, măsurile speciale de investigaţii judiciare şi extrajudiciare, a fost apreciat că, deşi ambele forme converg către un scop similar, garanţiile oferite le diferenţiază iar finalitatea acestora este

${ }^{10}$ I. Botnarii, „Nomenclatorul, criteriile de clasificare și categoriile măsurilor speciale de investigații”, în Revista Legea și Viața, Martie 2018, p. 4042, și V. Mârzac, B. Glăvan, „Utilizarea mijloacelor tehnice în activitatea specială de investigații”, Academia de Poliție Ștefan cel Mare, 2014. 
cu totul alta. Prin măsurile extrajudiciare sunt colectate informaţii referitoare la intenţii criminale, pregătiri a unor acţiuni ilicite, ca formă incipientă sau de pregătire a unei infracţiuni, spre deosebire de cele judiciare care colectează elemente ce ţin de descoperirea infracţiunilor ca fapt material şi realizarea actului de justiţie ${ }^{11}$.

În doctrina, se identifică posibilitatea persoanei vătămate într-un drept al său de către o autoritate publică, de a fi îndreptăţită să obţină recunoaşterea dreptului abuzat $^{12}$. In cadrul unei astfel de realizări eficiente, se apreciază că se deschid la un nivel mai înalt pârghiile legale disponibile ţinându-se cont de actul de reglementare, astfel: a) norma procesuală: Codul de procedură penală care prevede o serie de drepturi şi libertăţi ce pot fi aparate prin contestarea acţiunilor şi actelor organelor de urmărire penală; b) norma constituţională: Constituţia care prevede drepturile şi libertăţile omului recunoscute ca fundamentale; c) norma internaţională: Convenţia Europeană pentru drepturile omului şi libertăţilor fundamentale şi alte acte internaţionale incidente, la care Republica Moldova este parte, normele internaţionale având prioritate în faţa normelor interne.

Importanţa judecătorului de instrucţie, ca subiect special împuternicit să exercite controlul judecătoresc în procedura prejudiciară este abstractizată ca sancţiune prin controlul prealabil al legalităţii şi temeiniciei actelor şi acţiunilor pe care trebuie să le înfăptuiască organul de urmărire penală, dar şi ca autorizare pentru acţiunile de urmărire penală care limitează inviolabilitatea persoanei, domiciliului, corespondenţei, convorbirilor telefonice, comunicărilor telefonice şi a altor comunicări şi alte acţiuni prevăzute de lege, prevăzute atât de normele procesual-penale cât şi de cele operativ-investigative, atât anterior şi ulterior materializării.

În privinţa diferenţierii ca procedură de examinare a materialelor ce confirmă necesitatea solicitării unor activităţi de îngrădire a drepturilor unei persoane sau de intruziune în proprietatea acesteia, se constată că măsurile speciale de investigaţii sunt aşezate pe recomandări de parcurs, iar normele procesuale au reglementări clare şi detaliate, susţinând ideea că măsurile operative de investigaţii ce limitează drepturi ocrotite prin lege să fie admise doar în scopul culegerii informaţiilor despre persoanele care pregătesc sau care atentează să comită infracţiuni grave.

Controlul asupra măsurilor speciale de investigaţii este văzut ca o condiţie obligatorie în scopul realizării obiectivelor specifice, sarcina de bază fiind legalitatea şi motivarea activităţilor investigativ-operative, cu respectarea drepturilor

${ }^{11}$ T. Osoianu, V. Orîndaș, Procedură penală. Partea generală. Curs universitar, Chișinău, 2004, p. 45.

12 I. Dolea et. al., Tratat de drept procesual penal, Editura Cartier Juridic, Chișinău, 2005, p. 605. 
constituţionale ale persoanelor ce sunt sau urmează a fi îngrădite, atât în materie procesual-penală cât şi extra-procesuală ${ }^{13}$.

Problematica măsurilor speciale de investigaţii a fost abordată şi în alte materiale de către autorul Dolea I. ${ }^{14}$, fiind de părerea că aplicarea legislaţiei cu privire la activitatea operativă de investigaţii în cadrul procesului penal produce sincope, argumentând aspectul legat de valoarea probatorie a rezultatelor acestora prin asimilarea în categoria mijloacelor de probă şi respectarea condiţiilor de autenticitate şi posibilităţii de verificare aşa cum sunt enumerate în procedura penală.

In Tratatul Comentariu aplicativ al Codului de procedură penală, realizat de acelaşi autor, măsurile speciale de investigaţii sunt analizate în lumina modificărilor legislative, atât din perspectiva valorii probante cât şi din cea a garanţiilor asigurate de normele procesual penale. Autorul lasă să se înţeleagă că necesitatea intruziunilor în viaţa privată a unei persoane poate fi justificată numai dacă, printr-o altă măsură, mai puţin intruzivă, nu se poate aduce la îndeplinire scopul investigaţiei, fiind atins nivelul de exigenţă prevăzut de materia Curţii Europene.

Analizând conceptul juridic al măsurilor şi metodelor speciale de investigaţii, prin compararea normelor de reglementare, autorii Roman D. şi Popa S. apreciază că prin desfăşurarea activităţilor speciale de investigaţii prevăzute de Legea nr. 59/2012, în condiţiile Codului de procedura penală modificat prin Legea nr. 66/2012, acestea sunt asimilate şi definitoriu ca, „totalitate de acţiuni de urmărire penală cu caracter public şi/sau secret efectuate de către ofiţerii de investigaţii în cadrul urmăririi penale numai în condiţiile şi în modul prevăzut de cod, aşa cum sunt prevăzute în dispoziţiile generale privind activitatea specială de investigaţiì" (Art. $132^{1}$ alin. (1) din C.pr.pen. al R.M.).

În această situaţie, s-a identificat un conflict al definiţiilor prin faptul că norma procesual-penală priveşte acţiuni de urmărire penală efectuate doar după începerea urmăririi penale. Norma specială priveşte posibilitatea efectuării măsurilor speciale de investigaţii atât în cadrul procesului penal cât şi în afara acestuia autorii prezumând că anumite măsuri speciale de investigaţii urmează a fi efectuate după înregistrarea infracţiunii, până la începerea urmăririi penale, în termenul legal, iar anumite măsuri speciale de investigaţii pot fi efectuate numai după începerea urmăririi penale, conform prevederilor C.pr.pen. R.M., fiind create impedimente în aplicarea eficientă a legii în activitatea de prevenire, depistare şi investigare a infracţiunilor. În acest sens, au definit „activitatea specială de investigații, ca totalitatea de procedee probatorii cu caracter secret şi/sau public, efectuate de autorităţile competente, până la sesizarea/autosesizarea organelor de drept, în cadrul procesului penal şi/sau urmăririi penale, în scopul culegerii de informaţii necesare

13 V. Moraru, I. Covalciuc, „Particularitațile exercitării controlului asupra măsurilor speciale de investigații autorizate de către procuror”, în Revista Legea și Viața, nr. 12/2016, p. 47.

${ }^{14}$ I. Dolea, Drepturile persoanei în probatoriul penal. Concepția promovării elementului privat, Editura Cartea Juridică, Chișinău, 2009, p. 168. 
pentru prevenirea şi combaterea criminalităţii, asigurarea securităţii statului, ordinii publice, apărarea drepturilor şi intereselor legitime ale persoanelor, descoperirea şi cercetarea infracţiunilor".

Pentru a evidenţia şi din perspectivă teoretică măsurile speciale de investigaţii definite generic în procedura penală, au reliefat că acestea au ca element concret, metoda, care le determină conţinutul şi care prin elementul tactic clasificat, le diferenţiază de urmărirea penală. Exemplificând pe forma legii, autorii au asociat măsuri speciale şi metode tactice, astfel, măsura specială, urmărirea vizuală, are ca metodă urmărirea, supravegherea operativă nemijlocită, iar metoda, informare electronică, poate fi aplicată limitat şi condiţionat de obiectul ţintă şi mijloacele tehnice folosite ${ }^{15}$.

Este de interes modalitatea în care autorii au abordat una din sarcinile activităţii speciale de investigaţii, şi anume relevarea atentatelor criminale, prevenirea, curmarea infracţiunilor şi identificarea persoanelor care le organizează şi/sau comit. Astfel, indiferent pe care direcţie s-ar merge, în sensul conţinutului sarcinii, identificarea persoanei este esenţială, iar pentru îndeplinirea sarcinii este necesar a se efectua un cumul de activităţi speciale informativ-operative precum şi de căutare-identificare. A fost evidenţiată diferenţa dintre identificarea persoanei prin măsuri speciale de investigaţii, ca identificare neprocesuală şi procedura activităţii prezentării pentru recunoaştere, şi care permite în scopul realizării, utilizarea diferitelor metode şi mijloace de stabilire a identităţii, ambele având în comun metodele identificării criminalistice. A fost realizată o clasificare a elementelor, ca acţiuni în scopul identificării persoanelor şi a felurilor identificării, astfel, primele fiind materializate prin acţiuni de acumulare a informaţiei, cu obiect bine determinat şi acţiuni ce stabilesc asemănarea cu obiectul de identificat, care pot fi elemente ale măsurii de identificare a persoanei sau elemente pentru alte măsuri speciale, iar secundele, prin nemijlocite/mediate, public/cifrat sau secret.

Relevantă este concluzia autorilor materialului, în sensul că, pentru organele de anchetă, identificarea persoanei prin măsuri şi metode speciale este oportună şi necesară în situaţia în care autorul unei infracţiuni nu poate fi altfel identificat, rezultatele obţinute având rolul de a oferi sprijin pentru căutarea probelor şi stabilirea căilor de investigaţie, exclus fiind recunoaşterea acestora ca probe în procesul penal ${ }^{16}$.

Utilizarea măsurilor operative de investigaţii în activitatea de prevenire şi combatere a faptelor de corupţie, ca fenomen antisocial, ce posedă o individualitate bine marcată, atât juridico-penal cât şi a particularităţilor tacticii şi metodologiei descoperirii, fiind strâns legată inclusiv de crima organizată, ce pune în pericol valorile democratice, inclusiv drepturile şi libertăţile fundamentale ale omului şi buna funcţionare a instituţiilor statului. $\mathrm{Cu}$ privire la activitatea de investigarecercetare a evidenţiat diversitatea modalităţilor de efectuare a unei urmăriri penale

15 D. Roman, S. Popa, „Identificarea persoanei prin măsuri şi metode speciale de investigații”, în Studia Universitatis Moldaviae, Seria științe juridice, nr. 3 (103)/2018, pp. 193-195.

${ }^{16}$ Idem, pp. 196- 200. 
complexe prin îmbinarea măsurilor operative de investigaţii cu alte procedee extrajudiciare, în scopul unic de aflare a adevărului. În opinia sa, criminalistica este vitală, deoarece, prin utilizarea tuturor mijloacelor tehnico-ştiinţifice, tactice şi metodologice, bazate pe o planificare judicioasă în care se prevede cu exactitate locul efectuării actelor de investigare, momentele specifice cazului concret şi caracteristicile persoanelor implicate la realizarea lor, se acumulează materialul probator atât pentru faptele reconstituite cât şi flagrante. Despre testarea poligraf, ca o măsură operativă de investigaţii, remarcă faptul că rezultatul nu constituie mijloc de probă, dar în genere este utilizat la pregătirea unei anchete penale, ca date de interes în efectuarea a unor măsuri operative de investigaţii, iar ca probă doar cu respectarea prevederilor C.pr.pen. R.M., nerespectarea condiţiei imperative determinând încălcarea principiului prezumţiei de nevinovăţie ${ }^{17}$.

Aşa cum remarcă autorii Cobîrşenco I. şi Fala M. ${ }^{18}$, proporţionalitatea semnifică un echilibru just şi imperativ de menţinut între intruziunea în viaţa privată a persoanei şi importanţa faptică privind o anchetă, astfel încât autorizarea unei măsuri să se facă în concordanţă cu gravitatea faptei.

În materia respectării secretului corespondenţei, sunt evocate garanţiile constituţionale privind secretul scrisorilor, telegramelor, altor trimiteri poştale, al convorbirilor telefonice şi al celorlalte mijloace legale de comunicare dar şi norma de excepţie, derogare naţională, ingerinţa necesară în interesele securităţii naţionale, bunăstării economice a ţării, ordinii publice şi în scopul prevenirii infracţiunilor. În materia garanţiilor internaţionale, articolul 8 alin. (2) CEDO, menţionează că „nu este admis amestecul unei autorităţi publice în exercitarea acestui drept decât în măsura în care acest amestec este prevăzut de lege şi dacă constituie o măsură care, într-o societate democratică, este necesară pentru securitatea naţională, siguranţa publică, bunăstarea economică a ţării, apărarea ordinii şi prevenirea faptelor penale, protejarea sănătăţii sau a moralei, ori protejarea drepturilor şi libertăţilor altora", prevedere care este generatoare atât de drept cât şi de obligaţie. Ca prim procedeu de probaţiune, în Codul de procedură penală se menţionează că dreptul la secretul scrisorilor, al telegramelor, altor trimiteri poştale, convorbirilor telefonice şi al celorlalte mijloace legale de comunicare este asigurat de stat. Limitarea acestui drept se admite numai în baza unui mandat judiciar emis în condiţiile legii. Ținând cont de faptul că procesul penal are ca scop protejarea persoanei, societăţii şi statului de infracţiuni, precum şi protejarea persoanei şi societăţii de faptele ilegale ale persoanelor cu funcţii de răspundere în activitatea lor legată de cercetarea infracţiunilor presupuse sau săvârşite, este necesar ca organul de urmărire penală în procesul urmăririi penale să efectueze un anumit număr de acţiuni procesuale, ca necesare cu privire la stabilirea existenţei infracţiunii, identificarea făptuitorului şi a se constata dacă este sau nu cazul să se transmită cauza penală în judecată în condiţiile legii.

17 V. Cușnir, Corupția. Reglementare de drept, activități de prevenire și combatere. Partea I, Academia de Poliție Ștefan cel Mare, Chișinău, 1999, pp. 83-138.

${ }^{18}$ I. Cobîrșenco, M. Fală, „Principiul proporționalității măsurilor special de investigații. Garanția dreptului la viață privată”, în Revista Națională de Drept, nr. 12/2017, p. 4856. 
Un procedeu probatoriu secund prin care organul de urmărire penală poate administra probe este cel privind măsurile speciale de investigaţii întreprinse în cadrul activităţii speciale de investigaţii. În înţelesul Recomandării (2005) 10 a Comitetului de Miniştri al Consiliului Europei, prin noţiunea de tehnici speciale de investigare se înţelege tehnicile aplicate de autorităţile competente în cadrul anchetelor penale, vizând depistarea sau anchetarea unor infracțiuni grave şi a unor suspecţi în vederea colectării de informaţ̧ii, de aşa manieră încât persoanele în cauză să nu aibă cunoştinţă de acest lucru. Întrucât asemenea definire se regăseşte şi în art. 132 alin. (1) C.pr.pen. R.M., autorii apreciază că situaţia în cauză este în prezenţa a două legi, ambele conţinând norme cu privire la activitatea specială de investigaţii, însă, în conformitate cu art. 2 alin. (4) C.pr.pen., normele juridice cu caracter procesual din alte legi naţionale pot fi aplicate numai cu condiţia includerii lor în C.pr.pen.

Sunt enumerate măsurile speciale de investigaţii care aduc atingere nemijlocit dreptului secretului corespondenţei: interceptarea şi înregistrarea comunicărilor sau a imaginilor; reţinerea, cercetarea, predarea, percheziţionarea sau ridicarea trimiterilor poştale; monitorizarea conexiunilor comunicaţiilor telegrafice şi electronice; monitorizarea sau controlul tranzacţiilor financiare şi accesul la informaţia financiară; colectarea informaţiei de la furnizorii de servicii de comunicaţii electronice. Pentru ca aceste măsuri să aibă un caracter legal, este necesar să fie îndeplinite următoarele condiţii: a) este imposibilă realizarea scopului procesului penal şi/sau poate fi prejudiciată considerabil activitatea de administrare a probelor; b) există o bănuială rezonabilă cu privire la pregătirea sau săvârşirea unei infracţiuni grave, deosebit de gravă sau excepţional de gravă, cu excepţiile stabilite de lege; c) acţiunea este necesară şi proporţională cu restrângerea drepturilor şi libertăţilor fundamentale ale omului.

$\mathrm{Cu}$ referire la aceleaşi criterii de stabilire a proporţionalităţii, autorii abordează şi dreptul la inviolabilitatea domiciliului, în cadrul efectuării măsurilor speciale de investigaţii, astfel de la norma constituţională se poate deroga prin lege, pentru: executarea unor mandate de arestare sau a unei hotărâri judecătoreşti; înlăturarea unei primejdii care ameninţă viată, integritatea fizică sau bunurile unei persoane; prevenirea răspândirii unei epidemii. Materia procesual penală permite efectuarea percheziţiilor, cercetării domiciliului, care sunt ordonate şi efectuate în baza unor mandate judiciare iar cu privire la măsurile speciale de investigaţii ce aduc atingere acestui drept, organele de urmărire penală sunt în drept a efectua: cercetarea domiciliului şi/sau instalarea în el a aparatelor ce asigură supravegherea şi înregistrarea audio şi video, a celor de fotografiat şi de filmat; supravegherea domiciliului prin utilizarea mijloacelor tehnice ce asigură înregistrarea; investigaţia sub acoperire, care în mod obligatoriu se materializează în documente şi sunt supuse anumitor termene. Se concluzionează că principiul proporţionalităţii între dreptul sau libertatea persoanei garantate de lege şi necesitatea efectuării acţiunii procesuale solicitate recunoaşte că drepturile omului nu sunt absolute şi exercitarea drepturilor unei persoane trebuie să fie apreciată în raport cu interesul 
public mai larg, statele bucurându-se de o anumită marjă de apreciere în materia impunerii unor restricţii, marjă care nu este nelimitată.

Este interesantă abordarea autorului Copeţchi S. ${ }^{19}$, care în mod obiectiv analizează situaţia investigatorului sub acoperire, ca ofiţer de investigaţii antrenat în realizarea investigaţiei, fiind în acord cu prevederile art. 30 alin. (4) din Legea M.S.I., unde sunt definiţi ca angajaţi special desemnaţi din cadrul M.A.I., S.I.S., C.A.N., Departamentul Instituţiilor penitenciare din cadrul Ministerului Justiţiei. Ofiţerul de investigaţii, în exercitarea atribuţiilor de culegere a datelor şi informaţiilor despre pregătirea ori comiterea unei infracţiuni, poate determina prin comportamentul său acţiuni, situaţie care generează depăşirea limitelor de competenţă, rolul acestuia fiind de a observa discret. S-a potenţat diferenţa între provocare şi folosirea tehnicilor legale în activităţile specifice sub acoperite în cadrul dosarelor penale, clarificări în acest sens materializându-se oficial prin Hotărârea Plenului CSJ a R.M. nr. 11/22.12.2014 cu privire la aplicarea legislaţiei referitoare la răspunderea penală pentru infracţiunile de corupţie, în materia condiţiilor în care trebuie reţinută provocarea. Aceste condiţii sunt: acţiunea presupusă ca act de corupere să fie probată prin solicitarea venită de la persoana care avea atribuţia descoperirii infracţiunii sau există o determinare directă de la un denunţător; fapta nu s-ar fi comis fără intervenţia provocării; nu există suspiciuni anterioare privind implicarea în fapte de corupţie. Curtea apreciază că statul trebuie să descopere infracţiuni, nu să încurajeze săvârşirea acestora, astfel în mod inadmisibil există riscul provocării unei persoane nevinovate, recunoscând-o fictiv ca vinovată de faptă.

In aceeaşi ordine de idei, analizând raţionamentele art. 6, part. 1 CEDO referitoare la acţiunile de provocare organizată, Eni $\mathrm{A}^{20}$. apreciază că acestea pot îmbrăca forma instigării la săvârşirea de infracţiuni, abordându-se în acest sens garanţii suplimentare dreptului persoanei de a nu fi judecată în baza probelor acumulate. S-a argumentat exemplificând cu hotărâri CtEDO ce vizează cetăţeni ai R.M.: (i) în cauza Sandu contra Republicii Moldova unde o persoană a acţionat sub conducerea poliţiei ca o persoană privată (fără a avea investirea legală), iar acţiunile acesteia aveau trăsăturile unei investigaţii sub acoperire, caracterul provocator al comportamentului său fiind cercetat ca şi o provocare la săvârşirea infracţiunii din partea unui agent public - investigator sub acoperire; (ii) cauza Morari contra Republicii Moldova, care este realizată de către agenţii publici sub acoperire, adică angajaţi, special desemnaţi în acest scop, din cadrul Ministerului Afacerilor Interne.

Manualul judecătorului pentru cauze penale ${ }^{21}$ are ca punct de plecare necesitatea ca orice proces să aibă la bază principiul respectării demnităţii umane

19 S. Copețchi, „Provocarea infracțiunii în contextul măsurilor speciale de investigații”, în Revista Institutului Național al Justiției, nr. 2(41)/2017, p. 2732.

${ }^{20}$ A. Eni, „Analiza hotărârilor CtEDO adoptate în privința Republicii Moldova în materia admisibilităţii tehnicilor de utilizate în operațiunile sub acoperire în cadrul investigațiilor penale”, în Revista Studia Universitas Moldaviae, nr. 8 (118)/2018, p. 8091.

${ }^{21}$ M. Poalelungi, I. Dolea et. al., Manualul judecătorului pentru cauze penale, Chișinău, 2013, p. 1192. 
(statul devenind responsabil pentru orice act care îi lezează drepturile şi libertăţile fundamentale cetăţeanului; prezumţia de nevinovăţie însoţind orice demers, judecătorul adoptând un anumit tip de comportament). Se instituie astfel un veritabil sistem de garanţii procesuale în materie penală, de fiecare dată acţiunile sale bazându-se pe reguli cu caracter general în aprecierea unor situaţii cu caracter specific.

În România, tehnicile speciale de supraveghere sau cercetare constituie o categorie de procedee probatorii şi măsuri de investigaţie cu caracter derogatoriu de la regulile de drept comun privind administrarea probelor, fiind recunoscute la nivel internaţional ca un instrument în combaterea infracţionalităţii de mare gravitate. Chiar dacă o parte din aceste tehnici erau cunoscute şi întrebuinţate în procesul penal de mai mult timp, chiar fiind prevăzute în recomandări şi convenţii internaţionale, legiuitorul român a preluat noţiunea de tehnici speciale de investigare în urma Recomandării (2005) 10 a Comitetului de Miniştri al Consiliului Europei ${ }^{22}$.

Din definiţia dată de către Comitet se reţine că: „prin tehnici special de investigare, se înţeleg tehnicile aplicate de autorităţile competente în contextual investigaţiilor penale în scopul descoperirii şi cercetării infracţiunilor grave şi a suspecților, în vederea colectării informaţiilor astfel de o manieră în care să nu alerteze persoanele vizate de aceste tehnici”. Din această definiţie rezultă două aspecte importante şi anume: necesitatea restrângerii folosirii tehnicilor speciale de investigare numai la infracţiunile grave şi caracterul secret al acestora ${ }^{23}$.

Măsurile de supraveghere tehnică reprezintă una dintre cele mai severe intruziuni în viaţa privată a persoanei, astfel că s-a urmărit corelarea legislaţiei procesual-penale la aceste metode investigative moderne, demersuri destinate asigurării conformităţii între reglementarea procesual-penală şi exigenţele legii fundamentale, astfel cum acestea sunt edictate în Constituţia României precum şi cu cerinţele normative şi jurisprudenţiale izvorâte din articolul 8 al Convenţiei europene a drepturilor omului. În acest proces de elaborare a legislaţiei corespunzătoare, aflat într-o continuă dinamică determinată de evoluţia atât a metodelor tehnice, dar şi a viziunii Curţii Europene de Drepturilor Omului asupra metodelor de cercetare specială, principala dificultate a fost şi este reprezentată de găsirea unui cadru normativ adecvat, simplu şi predictibil, care să satisfacă necesitatea combaterii şi descoperirii infracţiunilor, dar şi să limiteze ingerinţa în drepturile fundamentale ale persoanei.

Apreciem că se impune a se menţiona faptul ca în mod frecvent se utilizează termenii de măsură şi tehnică, ambele făcând referire la acelaşi obiect, situaţie în care susţinem că nu se creează nicio diferenţiere, cu toate că la nivel internaţional este uzitat cu o mai mare frecvenţă termenul de tehnică.

${ }^{22}$ Recomandarea (2005) 10 a Comitetului de Ministri a Europei adoptata de Comitetul de Ministri la data de 20.04.2005.

${ }^{23}$ N. Bradley, "Evidence, special investigative techniques the right to a fair hearing", în Revista ERA Forum, vol.15, nr. 1/2014, p. 37. 
În doctrină, s-a arătat faptul că tehnicile speciale de investigare sunt procedee probatorii cu caracter derogatoriu, cu reguli şi proceduri particulare de autorizare, dar şi de punere în aplicare ${ }^{24}$. Ţinând cont de sfera de aplicare şi natura fiecăreia, acestea au şi un caracter propriu, eterogen ${ }^{25}$, aspect apreciat ca favorabil prin reglementarea clară şi delimitarea de procedeele comune întrucât acestea reprezintă o mare ingerinţa în viaţa privată a unei persoane ${ }^{27}$. S-a mai apreciat că spre deosebire de prevederile anterioare, legislaţia procesual-penală actuală realizează o buna sistematizare a acestora, uşurând aplicarea de către organele de urmărire penală, necesita o mai mare abstractizare şi o mai mare coerenta în reglementare.

În literatura de specialitate, s-a apreciat că pentru realizarea scopului procesului penal, acesta este călăuzit de reguli fundamentale ce fixează cadrul juridic care stabileşte limitele în care societatea trebuie să reacţioneze faţă de cei care încalcă legea penală ${ }^{26}$.

Codul de procedura penală român ${ }^{27}$ actual foloseşte noţiunile de probă şi mijloc de probă, la care se adaugă şi reglementarea unor procedee probatorii fără însă a le defini ca atare, aşa cum arată Titlul IV dar şi Capitolul IV Metode speciale de supraveghere sau cercetare.

În această situaţie şi metodele speciale de supraveghere sau cercetare se subordonează principiilor care guvernează procesul penal. Acestea sunt reglementate de prevederile articolele 212 din noul C.pr.pen Rom. ${ }^{28}$, fiind următoarele: principiul legalităţii procesului penal, principiul separării funcţiilor judiciare, prezumţia de nevinovăţie, principiul aflării adevărului, principiul ne bis în idem, principiul oficialităţii procesului penal, caracterul echitabil şi termenul rezonabil al procesului penal, garantarea dreptului la libertate şi siguranţă, garantarea dreptului la apărare, respectarea demnităţii umane şi a vieţii private, desfăşurarea procesului penal în limba română şi dreptul la asistenţă gratuită din partea unui interpret. În afară de acestea, există principii sau trăsături specifice aplicabile numai în faza de urmărire penală, respectiv numai în faza de judecată.

Alţi autori ${ }^{29}$ consideră că principiile specifice fazei de urmărire penală sunt în număr de trei, respectiv caracterul nepublic, caracterul necontradictoriu şi caracterul preponderent scris al urmăririi penale. La acestea alţi autori ${ }^{30}$ adaugă şi un al patrulea principiu, respectiv subordonarea ierarhică în efectuarea actelor de

${ }^{24}$ G. Mateuț., Procedura penală, Editura Universul Juridic, București, 2019, p. 1075.

${ }^{25}$ M. Bulancea, G. Zlati, R. Slăvoiu, în M. Udroiu (coordonator), Codul de procedură penală, Editura C.H. Beck, Bucureşti, 2017, p. 2571.

${ }^{26}$ G. Mateuț, „Observații critice privind noua reglementare a supravegherii tehnice întro perspectivă comparativă”, în Caiete de Drept Penal, nr. 3/2015, p. 13.

${ }^{27}$ I. Neagu, Drept procesual penal. Partea generală, București, 1981.

${ }^{28}$ Legea nr. 135/2010 privind Codul penal și Codul de procedură penală al României, publicată în Monitorul oficial nr. 486 din 15.06.2010.

${ }^{29}$ M. Udroiu, Procedură penală. Partea specială, ed. 3, Editura C.H. Beck, București, 2016, p. 23.

${ }^{30}$ N. Volonciu, Tratat de procedură penală, vol. 2, Editura Paideia, București, 1996, p. 1112. 
urmărire penală. Dintre acestea, doar caracterul nepublic al urmăririi penale a primit o consacrare legală expresă, prin prevederile articolul 285 alin. (2) C.pr.pen. Rom.

Principiul legalităţii este reglementat în cuprinsul articolul 2 din C.pr.pen Rom. şi prevede că procesul penal se desfăşoară potrivit dispoziţiilor prevăzute în lege, aspect ce presupune ca legea trebuie să fie conformă cu standardele constituţionale şi de protecţie a drepturilor omului, fiind necesar ca acţiunile desfăşurate de organele judiciare să fie conforme cu prevederile legale.

În doctrină ${ }^{31}$, se mai face distincţia între legalitatea aplicabilă în majoritatea situaţiilor şi cea de excepţie care reprezintă o derogare prevăzută de lege de la principiul legalităţii, astfel ca actul efectuat în aceste condiţii nu înfrânge acest principiu.

Verificarea conformităţii cu normele constituţionale a generat o serie de interpretări. Astfel, s-a reţinut posibilitatea de a se putea verifica, din perspective nulităţii absolute, în faza judecăţii, dacă au fost respectate principiile legalităţii şi loialităţii administrării probelor, datorită regulii generale de a se invoca acest gen de nulitate în tot cursul procesului penal, iar în cazul unei astfel de constatări se va proceda la excluderea şi înlăturarea acestora din materialul probator al cauzei ${ }^{32}$.

Principiu fundamental al loialităţii administrării probelor procesului penal are rolul de a opri folosirea de metode interzise cu scopul precis de a se obţine probe. Loialitatea probelor instituie de asemenea interdiç̧ia şi în ceea ce priveşte folosirea provocării în scopul probării faptelor.

Autorul R.P. Răileanu ${ }^{33}$ a apreciat că în mod excepţional probele administrate cu încălcarea prevederilor legale (excepţie tortura şi tratamentele inumane sau degradante) pot fi folosite în procesele penale dacă prin aceasta nu se aduce atingere caracterului echitabil al procedurii în ansamblu.

În jurisprudenţa $\mathrm{CtEDO}^{34} \mathrm{~s}$-a apreciat ca provocarea la comiterea unei infracţiuni are loc atunci când agenţii statului nu au un comportament pasiv, ci incita comiterea unei infracţiuni o persoana care altfel nu ar fi comise, fiind importante motivele care au stat la baza deciziei de iniţiere a măsurii special şi a comportamentului agenţilor statului.

În scopul de a se afla adevărul, organele judiciare au îndatorirea de a face demersuri în acest sens prin administrarea probelor care sunt necesare lămuririi pe deplin a tuturor aspectelor cauzei, inclusiv prin utilizarea măsurilor speciale de supraveghere sau cercetare, atunci când nu există o altă posibilitate. Tot în aceeaşi virtute, utilizând şi principiul libertăţii probelor se acordă posibilitatea părţilor de a solicita administrarea de probe pe care le apreciază ca fiind utile şi concludente în vederea soluţionării cauzei, situaţie în care se impune a mai adaugă şi faptul că,

${ }^{31}$ V. Dongoroz et. al., Explicații teoretice ale Codului de procedură penală român. Partea generală, București, 1975.

32 Decizia nr. 802/2017 publicată în Monitorul Oficial nr. 116 din 06.02.2018.

${ }^{33}$ R.P. Răileanu, „Principiile fundamentale ale procesului penal român în lumina noului cod de procedura penală”, în Revista Dreptul, nr. 6/2014, p. 106.

${ }^{34}$ Cauza Pătrașcu contra României. 
în general părţile deţin mai multe informaţii despre împrejurările de fapt care se urmăresc a fi stabilite.

În doctrină ${ }^{35} \mathrm{~s}$-a considerat că aflarea adevărului este unul dintre obiectivele administrării de probe, fiind rezultatul clarificării cauzei sub toate aspectele, pe baza de probe.

Prin Codul de procedură penală român în vigoare, legiuitorul a urmărit să unifice procedeele probatorii cu caracter derogatoriu şi intruziv sub o singura formă de reglementare cu caracter unitar ${ }^{36}$, condiţiile rămânând egale dar procedurile de autorizare fiind diferite, unele fiind în competenta judecătorului de drepturi şi libertăţi iar altele la aprecierea procurorului.

Diferenţa între măsurile speciale de supraveghere şi măsurile speciale de cercetare nu este enunţată în cod, fiind lăsată la latitudinea doctrinei, urmare a menţiunii din cuprinsul articolul 138 alin. (13) C.pr.pen. Rom., în care se arată că prin supraveghere tehnică se înţelege utilizarea uneia dintre metodele prevăzute la alin. (1) li. a)-d.

Astfel, sunt considerate metode speciale de supraveghere: interceptarea comunicaţiilor ori a oricărui tip de comunicare la distanţă; accesul la un sistem informatic; supravegherea video, audio sau prin fotografiere; localizarea sau urmărirea prin mijloace tehnice, iar metode speciale de cercetare : obţinerea datelor privind tranzacţiile financiare ale unei persoane; reţinerea, predarea sau percheziţionarea trimiterilor poştale; utilizarea investigatorilor sub acoperire şi a colaboratorilor; participarea autorizată la anumite activităţi; livrarea supravegheată.

Diferenţa dintre metodele speciale de supraveghere şi metodele speciale de cercetare ar putea fi stabilită prin utilizarea criteriului referitor la faptul că, în cazul măsurilor de supraveghere, organele de urmărire penală primesc informaţiile chiar în timp ce se desfăşoară activităţile, dar în cazul măsurilor speciale de cercetare, organele de urmărire penală primesc informaţiile despre activităţi, după ce acestea au avut loc.

In vederea interpretării logice a limitelor între metodele speciale de supraveghere şi metodele speciale de cercetare, au fost identificate caracteristici care oferă clarificări şi utilitate stadiului actual de utilizare a tehnicilor speciale de investigare. Astfel a fost realizată o clasificare după 1) organul care autorizează măsura judecător de drepturi sau libertăţi sau procuror, 2) nivelul de intruziune în viaţa privată a unei persoane, 3) tipul de activitate, în timp real sau după consumarea faptelor, 4) complexitatea activităţii ${ }^{37}$. Or, tot în doctrină s-a susţinut necesitatea punerii în valoare a judecătorului, ca unic garant viabil al respectării drepturilor şi libertăţilor persoanei în cadrul unui proces penal ${ }^{38}$.

${ }^{35}$ G. Antoniu, „Observații la proiectul noului Cod de procedura penală”, în Revista de drept penal, nr. $1 / 2009$.

${ }^{36}$ M. Udroiu, R. Slăvoiu, O. Predescu, Tehnici speciale de investigare în justiția penală, Editura C.H. Beck, București, 2009, p. 225.

${ }^{37}$ Ibidem, pp. 304-305.

${ }^{38}$ G. Mateuț, Observații critice ..., op. cit., p. 13. 
Se poate concluziona cu faptul că se impune stabilirea de condiţii universale pentru toate tehnicile speciale de investigare, condiţiile referitoare la existenţa unei urmăriri penale începute (in rem sau in personam), respectarea proporţionalităţii măsurii cu scopul urmărit şi subsidiaritatea acesteia faţă de alte procedee probatorii mai puţin intruzive.

Interceptarea comunicaţiilor ori a oricărui tip de comunicare la distanţa a fost definită în doctrină $\breve{c}^{39}$ ca fiind o măsură de supraveghere care include atât interceptarea propriu-zisă, cât şi activităţile conexe acces, monitorizare, colectare sau înregistrare, necesare pentru a transforma conţinutul unei comunicări într-un mijloc de probă.

Accesul la un sistem informatic presupune căutarea şi identificare probelor aflate întruna dispozitiv de prelucrare automată a datelor calculator, tabletă, telefon, sau intru mijloc de stocare hard disk, cd, memory stick, prin folosirea de procedee tehnice care asigură confidenţialitatea acestui demers.

Supravegherea video, audio sau prin fotografiere reprezintă monitorizarea unei persoane şi înregistrarea imaginilor şi sunetelor surprinse cu această ocazie, asigurându-se în acest fel şi comunicările verbale sau mimico-gestuale.

Localizarea sau urmărirea prin mijloace tehnice este o activitate de monitorizare în timp real a deplasărilor pe care le efectuează o persoana, prin folosirea de dispozitive ataşate unor obiecte. Finalitatea acestei masuri este de a se stabili locul unde se afla sau unde efectuează deplasări o persoana.

Obţinerea de date privind tranzacţiile financiare este o măsură prin care se obţin date despre operaţiunile pe care o persoană le efectuează prin intermediul unei instituţii de credit, vizându-se atât tranzacţiile efective cat şi înscrisurile prin care se realizează.

În literatura de specialitate ${ }^{40}, \mathrm{~s}-\mathrm{a}$ menţionat că prin aceasta măsură se pot obţine şi conţinutul tranzacţiilor efectuate, IP-urile folosite în logarea în anumite aplicaţii Internet Banking, precum şi date la care a fost folosit serviciul.

Percheziţia trimiterilor poştale reprezintă verificarea conţinutului scrisorilor sau al coletelor transmise prin poştă sau curierat, activitate desfăşurată fără ştiinţa expeditorului sau a destinatarului.

Obţinerea datelor generate sau prelucrate de către furnizorii de reţele publice de comunicaţii ori furnizorii de servicii de comunicaţii electronice destinate publicului, reprezintă un procedeu prin care organele de cercetare penală intră în posesia datelor de identificare ale comunicării, percepută ca orice schimb de informaţii realizat prin intermediul unei rețele publice de comunicaţii electronice.

Supravegherea tehnică reprezintă aplicarea oricăror procedee incluse în aceasta categorie: interceptarea comunicaţiilor ori ale comunicării, accesul la un sistem informatic, supravegherea video, audio sau prin fotografiere, localizarea sau urmărirea prin mijloace tehnice. Se dispune de către judecătorul de drepturi şi libertăţi la solicitarea organului judiciar, dacă sunt îndeplinite cumulativ

\footnotetext{
${ }^{39}$ M. Bulancea, G. Zlati, R. Slăvoiu, în M. Udroiu (coordonator), op. cit., p. 2571.
}

${ }^{40}$ Ibidem, p. 653. 
următoarele condiţii: exista o suspiciune rezonabila cu privire la pregătirea sau săvârşirea unei infracţiuni dintre cele prevăzute în mod explicit (alin. (2)); măsura este proporţională cu restrângerea drepturilor şi libertăţilor fundamentale date fiind particularităţile cauzei, importanţa informaţiilor ori a probelor ce urmează a fi obţinute sau gravitatea infracţiunii; probele nu ar putea fi obţinute în alt mod sau obţinerea lor ar presupune dificultăţi deosebite ce ar prejudicia ancheta ori există un pericol pentru siguranţa persoanelor sau a unor bunuri de valoare.

Înregistrările la care face referire articolul 139 alin. (3) C.pr.pen. Rom. efectuate de părţi sau de alte persoane, constituie mijloc de probă când privesc propriile convorbiri sau comunicări pe care le-au purtat cu terţii. Orice alte înregistrări pot constitui mijloace de probă dacă nu sunt interzise prin lege.

Apreciem progresul legislativ, prin raportare la vechile norme procesual penale, prin aceea că a fost instituită procedura unitară de autorizare a măsurilor de supraveghere tehnică, în care rolul principal îl are judecătorul de drepturi şi libertăţi, de asemenea şi norma juridică este superioară prin aceea că nu transpune procedura interceptărilor şi înregistrărilor la alte măsuri de supraveghere tehnică, ci prevede că va trebui ca, pentru fiecare dintre măsuri să se procedeze la o analiză distinct, prin raportare la criteriile generale prevăzute la art. 139 C.pr.pen. Rom.

\section{Concluzii}

Reglementările legislative în vigoare în Republicii Moldova la capitolul măsurilor speciale de investigaţii îşi au sediul, atât în Codul de procedură penală, urmărind scopul soluţionării problemelor procesului penal, prin asigurarea probaţiunii urmăririi penale, cât şi în Legea specială nr. 59/2012 ca activităţi extra procesuale.

Reglementările legislative în vigoare în România la capitolul metodelor speciale de supraveghere sau cercetare sunt cuprinse exclusiv în Codul de procedură penală, în acest fel, legiuitorul urmărind realizarea probaţiunii în urmărirea penală şi implicit scopul procesului penal, prin asigurarea cadrului justificativ. Acestea sunt verificate periodic, urmare a sesizărilor transmise de diferite instanţe, sub aspectul încadrării în normele superioare protejate de către Curtea Constituţională.

Desigur că aceste norme sunt supuse permanent verificării prin aplicare practică, analiză doctrinară şi nu în ultimul rând constituţională, toate acestea cu tendinţa de a identifica soluţii şi teze ce ar asigura perfecţiunea şi compatibilitatea acestora cu normele internaţionale ce reglementează acelaşi domeniu.

\section{Referinţe}

Antoniu G., „Observaţii la proiectul noului Cod de procedura penală”, în Revista de drept penal, nr. 1/2009

Botnarii I., „Nomenclatorul, criteriile de clasificare şi categoriile măsurilor speciale de investigaţii”, în Revista Legea şi Viaţa, Martie 2018

Bradley N., „Evidence, special investigative techniques the right to a fair hearing”, în Revista ERA Forum, vol.15, nr. 1/2014 
Bulancea M., Zlati G., Slăvoiu R., în Udroiu M. (coordonator), Codul de procedură penală, Editura C.H. Beck, București, 2017

Carlaşuc I., „Regimul extrajudiciar al activităţii operative de investigaţii în realizarea sarcinilor stabilite prin lege", în Revista Teorii şi practici de guvernări democratice/Materialele sesiunii de comunicări ştiinţifice 23-24.10.2010

Cobîrşenco I., Fală M., „Principiul proporţionalităţii măsurilor special de investigaţii. Garanţia dreptului la viaţă privată”, în Revista Naţională de Drept, nr. 12/2017

Copeţchi S., „Provocarea infracţiunii în contextul măsurilor speciale de investigaţii”, în Revista Institutului Naţional al Justiţiei, Chişinău, nr. 2(41)/2017

Covalciuc I., „Actualitatea şi importanţa activităţii speciale de investigaţii în contextul ultimelor modificări legislative" în Buletinul Ştiinţific al Universităţii de Stat Bogdan Petriceicu Haşdeu, Ştiinţe sociale nr. 2(4)/2016

Covalciuc I., „Reflexii asupra evoluţiei istorice a reglementărilor normative privind activităţile speciale de investigaţii”, în Revista Naţională de Drept, nr. 11/2016

Cuşnir V., Corupţia. Reglementare de drept, activităţi de prevenire şi combatere. Partea I, Academia de Poliţie Stefan cel Mare, Chişinău, 1999

Dolea I et. al., Tratat de drept procesual penal, Editura Cartier Juridic, Chişinău, 2005, p. 605.

Dolea I., Drepturile persoanei în probatoriul penal. Concepția promovării elementului privat, Editura Cartea Juridică, Chişinău, 2009

Dongoroz V. et. al., Explicaţii teoretice ale Codului de procedură penală român Partea generală, Bucureşti, 1975.

Eni A., „Analiza hotărârilor CtEDO adoptate în privinţa Republicii Moldova în materia admisibilităţii tehnicilor de utilizate în operaţiunile sub acoperire în cadrul investigaţiilor penale”, în Revista Studia Universitas Moldaviae, nr. 8 (118)/2018

Mateuţ G., „Observaţii critice privind noua reglementare a supravegherii tehnice într-o perspectivă comparativă”, în Caiete de Drept Penal, nr. 3/2015

Mateuţ G., Procedura penală, Editura Universul Juridic, Bucureşti, 2019

Mârzac V., Glăvan B., „Utilizarea mijloacelor tehnice în activitatea specială de investigaţii”, Academia de Poliţie Ştefan cel Mare, 2014

Moraru V., Covalciuc I., „Particularitaţile exercitării controlului asupra măsurilor speciale de investigaţii autorizate de către procuror”, în Revista Legea şi Viaţa, nr. 12/2016

Neagu I., Drept procesual penal. Partea generală, Bucureşti, 1981

Osoianu T, Orîndaş V., Procedură penală. Partea generală. Curs universitar, Chişinău, 2004

Osoianu T., Reforma judiciară şi de drept în Republica Moldova. Condiţie necesară în vederea integrării europene. http: //www.ipp.md/old/print.php?l=ro\&idc=167\&id=495, p.1-2, 15 şi Apud din Мартынчик Е., Судебная власть в Молдове, часть первая (историкоправовые очерки), Изд-во ULIM, Chiєinгu, 1999

Poalelungi M., Dolea I. et. al., Manualul judecătorului pentru cauze penale, Chişinău, 2013

Răileanu R.P., „Principiile fundamentale ale procesului penal român în lumina noului cod de procedura penală”, în Revista Dreptul, nr. 6/2014

Roman D., Popa S., „Identificarea persoanei prin măsuri şi metode speciale de investigaţii”, În Studia Universitatis Moldavie, Seria ştiinţe juridice nr. 3 (103)/2018

Rusu V., Covalciuc I., „Unele reflecţii asupra sistemului şi conţinutului principiilor activităţii speciale de investigaţii”, în Revista Naţională de Drept, nr. 8/2015

Udroiu M., Procedură penală. Partea specială, ed. 3, Editura C.H. Beck, Bucureşti, 2016

Udroiu M., Slăvoiu R., Predescu O., Tehnici speciale de investigare în justiția penală, Editura C.H. Beck, Bucureşti, 2009

Volonciu N., Tratat de procedură penală, vol. 2, Editura Paideia, Bucureşti, 1996 